https://doi.org/10.15407/dopovidi2021.06.126

UDC 616.379-008.64:616.12:616.98

M.D. Tronko, https://orcid.org/0000-0001-7421-0981

S.A. Cherviakova, https://orcid.org/0000-0002-6917-5736

V.V. Pushkarev, https://orcid.org/0000-0001-5940-5510

Y.B. Belchina, https://orcid.org/0000-0002-4289-8977

O.I. Kovzun, https://orcid.org/0000-0001-8164-7671

V.M. Pushkarev, https://orcid.org/0000-0003-0347-7771

L.K. Sokolova, https://orcid.org/0000-0003-0011-0106

V.P. Komisarenko Institute of Endocrinology and Metabolism of the NAMS of Ukraine, Kyiv E-mail: pushkarev.vm@gmail.com

\title{
Apolipoprotein B and oxLDL levels in plasma of patients with diabetes, cardiovascular disease, and COVID-19
}

Presented by Corresponding Member of the NAS of Ukraine M.D. Tronko

Elevated levels of low-density lipoprotein ( $L D L-X)$ cholesterol, apolipoprotein B (ApoB), and especially oxidized $L D L$ in plasma are associated with an increased risk of cardiovascular disease (CVD). The aim of the study was to determine the levels of $A p o B$ and oxLDL in the blood of patients with diabetes mellitus (DM), CVD and COVID-19. $A p o B$ and oxLDL were determined using enzyme-linked immunosorbent assay kits (Elabscience, USA). The measurements were performed at an optical wavelength of $450 \mathrm{~nm}$. It was found that ApoB and oxLDL levels in the blood of patients with diabetes and, especially, with COVID-19 are substantially higher than in the blood of healthy people. Blood levels of ApoB and oxLDL are higher in patients with both COVID-19 and diabetes or CVD as compared to patients with COVID-19 without comorbidities. Thus, the levels of ApoB and oxidized LDL may be the promising markers of severe COVID-19.

Keywords: COVID-19, type 2 diabetes, cardiovascular disease, apolipoprotein B, oxidized LDL.

Hydrophobic lipids are insoluble in plasma, and, for the delivery to tissues, they have to be packaged into lipoproteins with cholesterol esters and triglycerides in the core and phospholipids, free cholesterol, and apolipoproteins on the surface. The hydrophobic core of low-density lipoprotein (LDL) is made of about 170 triglycerides, 1500 cholesterol esters, a hydrophilic coat composed of 700 molecules of phospholipids, about 500 molecules of unesterified cholesterol, and a single large copy of the ApoB of $500 \mathrm{kDa}$ [1]. Apolipoprotein B is the primary apolipopro-

Ци ту в ання: Tronko M.D., Cherviakova S.A., Pushkarev V.V., Belchina Y.B., Kovzun O.I., Pushkarev V.M., Sokolova L.K. Apolipoprotein B and oxLDL levels in plasma of patients with diabetes, cardiovascular disease, and COVID-19. Допов. Наи. акад. наук Укр. 2021. № 6. С. 126-130.

https://doi.org/10.15407/dopovidi2021.06.126 
tein and is the carrier for the following lipids: chylomicrons, LDL, very low-density lipoprotein (VLDL), intermediate-density lipoprotein (IDL), and lipoprotein (a). ApoB is not found in highdensity lipoproteins (HDL), the latter are reconstituted into lipoproteins with ApoA. Hepatic ApoB has a molecular mass of 540000 Da. There are two circulating forms of ApoB, ApoB48 (from small intestine) and ApoB100 (from liver) [2].

Under oxidative stress, the oxidation of LDL occurs by the process of lipid peroxidation primarily involving the phospholipid molecules. Under pathological conditions, ApoB-containing lipoproteins in the plasma penetrate through the damaged endothelium into vascular subendothelial intima getting oxidized by ROS. Thus, the LDL is modified into oxLDL [1].

It has been found that increased levels of low-density lipoprotein cholesterol (LDL-C), apolipoprotein $\mathrm{B}$, and especially oxLDL in plasma are associated with an increased risk of developing cardiovascular diseases (CVD). The ApoB/ApoA1 ratio has been found to be associated with type 2 diabetes and has been proposed as a novel biomarker for its prediction [3]. Meta-analysis also shows that increased ApoB and decreased ApoA1 levels, as well as the ApoB/A1 ratio, are risk factors for the first ischemic stroke [4].

Materials and Methods. The study was conducted in the diabetology department of the Institute. The study protocol was approved by the Institute's ethics committee. All patients signed informed consent to conduct the further diagnostic and research study.

Blood was obtained by standard venipuncture and stored in EDTA vacutainer tubes. Plasma was separated by centrifugation within $10 \mathrm{~min}$ after blood sampling. The samples were stored at $-80{ }^{\circ} \mathrm{C}$ until use. ApoB/oxLDL was determined $(n=81)$ using enzyme-linked immunosorbent assay (ELISA) kit (Elabscience, USA). The measurement was carried out at an optical wavelength of $450 \mathrm{~nm}$ on an immunoenzymatic plate analyzer Stat Fax 3200 (Awareness Technology, USA).

Glycated hemoglobin was determined using one HbA1c FS kit (DiaSys Diagnostic Systems $\mathrm{GmbH}$ (Germany). The measurement was carried out at an optical wavelength of $660 \mathrm{~nm}$.

Statistical analysis and data presentation were performed using the Origin 7.0 software. The results of the study are presented as $M \pm m$. To compare the data groups, Student's $t$-test was used. Values of $P \leqslant 0.05$ were considered as significant.

Results and discussion. The blood plasma of 60 type 2 diabetes patients and 21 patients with diabetes, CVD and COVID-19 was used. As a control, we used the blood of healthy people $(n=7)$ without concomitant diseases, representative of age. 4 patients had CVD in the anamnesis. The level of Hb1Ac in diabetic patients was $9.62 \pm 0.27$; BMI $-30.69 \pm 1.06 \mathrm{~kg} / \mathrm{m}^{2}$. The fasting glucose content in the blood of patients with COVID-19 and diabetes was $9.6 \pm 0.92 \mathrm{mmol} / \mathrm{l}$, at the time of discharge $-6.72 \pm 0.62 \mathrm{mmol} / \mathrm{l}$. Average $\mathrm{O}_{2}$ saturation was $87.3 \pm 0.7 \%$, which indicates a severe course of the disease.

The average level of ApoB in the blood of healthy people was $1.05 \mathrm{~g} / \mathrm{L}$, within the normal range (norm: $0.55-1.3 \mathrm{~g} / \mathrm{L}$ for men, and $0.6-1.4 \mathrm{~g} / \mathrm{L}$ for women) (Table). In diabetic patients, this indicator is higher $-1.15 \mathrm{~g} / \mathrm{L}-$ closer to the upper limit of the norm. In patients with COVID-19, the content of ApoB in blood is substantially higher, than control and norm values (see Table, lines 3-6). It is worth to note the difference between patients with COVID-19 without concomitant diseases and COVID-19 with diabetes and especially CVD (see Table, line 5 vs. lines 4 and 6 ). 
Almost the same pattern was observed with oxLDL (Table). In diabetic patients, the amount of oxLDL is higher than that of control level. In patients with COVID-19, the content of oxLDL in blood is much higher than control and diabetic patients levels (see Table, lines 3-6). There was also the significant difference between patients with COVID-19 without concomitant diseases and COVID-19 with diabetes and and CVD (see Table, line. 5 vs. lines 4 and 6). Thus, the amount of ApoB and LDL derivatives, oxLDL, changes in the blood of diabetic and COVID-19 patients almost synchronously.

It has been proven that a high content of low-density lipoproteins (LDL) causes the accumulation of cholesterol on the walls of blood vessels, significantly increasing the risk of atherosclerosis (AS) and CVD [5-7]. Due to the fact that ApoB is the main protein of LDL, which is, in turn, the main carrier of cholesterol to the cells, the determination of its concentration specifies the degree of risk of developing coronary heart disease. The concentration of ApoB in the blood is now considered a more reliable indicator of the risk of developing AS, than total cholesterol (TC) or LDL-cholesterol (LDL-C). Along with the determination of the ApoB concentration, the content of apolipoprotein $\mathrm{A} 1$ should also be determined. If the ratio of the concentrations of $\mathrm{ApoB}$ to ApoA1 is more than 1, then the risk of developing coronary heart disease is very high. It was proposed to set the limits of the norm for ApoB more than $1.2 \mathrm{~g} / \mathrm{L}$. For risk groups, it is recommended to maintain the ApoB content of less than $0.9 \mathrm{~g} / \mathrm{L}$ regardless of gender. With regard for the limit values of the ApoB/ApoA1 ratio, it can be used to determine the level of risk for men $<0.9$, and for women $<0.8)[6,8]$.

AS is characterized as a chronic inflammatory response to cholesterol deposition in arteries. LDL, especially the oxidized form - oxLDL, plays a crucial role in the occurrence and deve-

Plasma ApoB and oxLDL levels of patients with diabetes, CVD and COVID-19

\begin{tabular}{|c|c|c|c|c|}
\hline No. & Groups & ApoB, g/l & $m$ & $n$ \\
\hline $\begin{array}{l}1 \\
2 \\
3 \\
4 \\
5 \\
6\end{array}$ & $\begin{array}{l}\text { Contr. } \\
\text { DM } \\
\text { COVID-19 average } \\
\text { COVID-19 + DM } \\
\text { COVID-19, healthy } \\
\text { COVID-19+CVD }\end{array}$ & $\begin{array}{l}1.052 \\
1.154 \\
2.324 \\
2.433 \\
2.123 \\
2.620\end{array}$ & $\begin{array}{c}0.062 \\
0.036^{*} \\
0.089^{* *} \\
0.087^{* *} \\
0.064^{* *+} \\
0.148^{* *}\end{array}$ & $\begin{array}{c}7 \\
60 \\
21 \\
16 \\
5 \\
4\end{array}$ \\
\hline No. & Groups & oxLDL, pg/ml & $m$ & $n$ \\
\hline $\begin{array}{l}1 \\
2 \\
3 \\
4 \\
5 \\
6\end{array}$ & $\begin{array}{l}\text { Contr. } \\
\text { DM } \\
\text { COVID-19 total } \\
\text { COVID-19+DM } \\
\text { COVID-19, healthy } \\
\text { COVID-19+CVD }\end{array}$ & $\begin{array}{c}70.45 \\
102.07 \\
256.54 \\
268.46 \\
232.44 \\
281.50\end{array}$ & $\begin{array}{l}12.86 \\
7.87^{*} \\
7.01^{* *} \\
5.55^{* *} \\
9.8^{* *+} \\
8.02^{* *}\end{array}$ & $\begin{array}{c}7 \\
60 \\
21 \\
16 \\
5 \\
4\end{array}$ \\
\hline
\end{tabular}

Notes. 1 - control; 2 - patients with diabetes mellitus; 3 - average data for all patients with COVID-19; 4 - patients with COVID-19 and diabetes; 5 - patients with COVID-19 without concomitant diseases $(n=5)$; 6 - patients with COVID-19 and CVD $(n=4) . M \pm m$. There were significant differences between control and other groups: ${ }^{*} P<0.05 ;{ }^{*} P<<0.001 ;^{+}$differences from groups 4,6 are significant, $P<0.05$ 
lopment of AS by inducing endothelial cell dysfunction, attracting monocytes/macrophages, and promoting chronic inflammation. Macrophages engulf oxLDL to form foam cells that ultimately release pro-inflammatory cytokines and exacerbate local inflammation [7, 9].

We showed that both ApoB and oxLDL levels increased with high significance $\left(P=5.85 \cdot 10^{-8}\right.$ and $2.46 \cdot 10^{-11}$, respectively) that evidenced the rise of CVD risk.

The dyslipidemia associated with SARS has been repeatedly confirmed. However, other authors found that the levels of serum TC, HDL- and LDL-cholesterol were significantly lower in the COVID-19 patients as compared with normal subjects [9, 10]. It was concluded that patients with COVID-19 develop hypolipidemia, when symptoms are mild, and that hypolipidemia worsens with disease severity [10]. But those authors use "hypolipidemia" to refer to patients with total cholesterol $<174 \mathrm{mg} / \mathrm{dL}$. This definition of hypolipidemia is improper and substantially wrong in the absence of a genetic diagnosis. The prevalence of subjects at high cardiovascular risk could explain the observed findings on LDL-C. Low levels of LDL-C in this group were likely due to a more intensive lipid-lowering treatment [11]. In addition, we studied the content of ApoB, not LDL-C, and they may have different dynamics. The level of ApoA1 was significantly decreased in the blood of COVID-19 patients [12].

Conclusions. The levels of ApoB and oxLDL in the blood of patients with diabetes and, especially, COVID-19 were significantly higher than in the blood of healthy people.

There were differences between patients with COVID-19 without concomitant diseases and COVID-19 with diabetes or CVD.

The levels of ApoB and oxLDL may be the promising markers for COVID-19.

\section{REFERENCES}

1. Khatana, C., Saini, N. K., Chakrabarti, S., Saini, V., Sharma, A., Saini, R. V. \& Saini, A. K. (2020). Mechanistic Insights into the oxidized low-density lipoprotein-induced atherosclerosis. Oxid. Med. Cell. Longev., No. 2020, 5245308. https://doi.org/10.1155/2020/5245308

2. Devaraj, S., Semaan, J. R. \& Jialal, I. (2021). Biochemistry, apolipoprotein B. In StatPearls. Treasure Island (FL): StatPearls Publishing.

3. Mao, Y., Xu, Y. \& Lu, L. (2017). The nonlinear association between apolipoprotein B to apolipoprotein A1 ratio and type 2 diabetes. Medicine (Baltimore), 96, No. 1, e5834. https://doi.org/10.1097/MD.0000000000005834. Erratum: Medicine (Baltimore), 96, No. 12, e6541. Erratum: Medicine (Baltimore), 96, No. 17, e6821.

4. Dong, H., Chen, W., Wang, X., Pi, F., Wu, Y., Pang, S., Xie, Y., Xia, F. \& Zhang, Q. (2015). Apolipoprotein A1, $\mathrm{B}$ levels, and their ratio and the risk of a first stroke: a meta-analysis and case-control study. Metab. Brain Dis,. 30, No. 6, pp. 1319-1330. https://doi.org/10.1007/s11011-015-9732-7

5. Sokolova, L. K., Pushkarev, V. M., Pushkarev, V. V., Kovzun, O. I. \& Tronko, M. D. (2017). Diabetes mellitus and atherosclerosis. The role of inflammatory processes in pathogenesis (literature review). International journal of endocrinology (Ukraine), 13, No. 7, pp. 486-498 (in Russian). https://doi.org/10.22141/2224-0721.13.7.2017.115747

6. Sniderman, A. D., Thanassoulis, G., Glavinovic, T., Navar, A. M., Pencina, M., Catapano, A. \& Ference, B. A. (2019). Apolipoprotein B particles and cardiovascular disease: a narrative review. JAMA Cardiol., 4, No. 12, pp. 1287-1295. https://doi.org/10.1001/jamacardio.2019.3780

7. Yan, Y., Song, D., Wu, J. \& Wang, J. (2020). Long non-coding RNAs link oxidized low-density lipoprotein with the inflammatory response of macrophages in atherogenesis. Front. Immunol., No. 11, pp. 24. https://doi.org/10.3389/fimmu.2020.00024

8. Sokolova, L. K. (2014). Risk factors and clinical and diagnostic aspects of cardiovascular pathology in patients with types 1 and 2 diabetes mellitus. (Extended abstract of Doctor thesis). V.P. Komisarenko State 
Institute of Endocrinology and Metabolism of the National Academy of Medical Sciences of Ukraine, Kyiv, Ukraine (in Ukrainian).

9. Kočar, E., Režen, T. \& Rozman, D. (2021). Cholesterol, lipoproteins, and COVID-19: basic concepts and clinical applications. Biochim. Biophys. Acta. Mol. Cell Biol. Lipids, 1866, No. 2, 158849. https://doi.org/10.1016/j.bbalip.2020.158849

10. Wei, X., Zeng, W., Su, J., Wan, H., Yu, X., Cao, X., Tan, W. \& Wang, H. (2020). Hypolipidemia is associated with the severity of COVID-19. J. Clin. Lipidol., 14, No. 3, pp. 297-304. https://doi.org/10.1016/j.jacl.2020.04.008

11. Fogacci, F., Borghi, C. \& Cicero, A. F. G. (2020). Misinterpreting data in lipidology in the era of COVID-19. J. Clin. Lipidol., 14, No. 4, pp. 543-544. https://doi.org/10.1016/j.jacl.2020.07.004

12. Tronko, M. D., Cherviakova, S. A., Pushkarev, V. V., Belchina, Y. B., Kovzun, O. I., Pushkarev, V. M. \& Sokolova, L. K. (2021). Apolipoprotein A1 level in plasma of patients with diabetes and diabetics patients with COVID-19 as a possible marker of disease. Dopov. Nac. akad. nauk Ukr., No. 4, pp. 110-113.

https://doi.org/10.15407/dopovidi2021.04.110

Received 24.06.2021

М.Д. Тронько, https://orcid.org/0000-0001-7421-0981

С.A. Червякова, https://orcid.org/0000-0002-6917-5736

В.В. Пушкарьов, https://orcid.org/0000-0001-5940-5510

Ю.Б. Бельчина, https://orcid.org/0000-0002-4289-8977

O.I. Ковзун, https://orcid.org/0000-0001-8164-7671

В.М. Пушкарьов, https://orcid.org/0000-0003-0347-7771

Л.К. Соколова, https://orcid.org/0000-0003-0011-0106

ДУ “Інститут ендокринології та обміну речовин ім. В.П. Комісаренка НАМН України”, Київ

E-mail: pushkarev.vm@gmail.com

РІВЕНЬ АПОЛІПОПРОТЕЇНУ В ТА оXLDL

У ПЛАЗМІ ПАЦІЄНТІВ ІЗ ДІАБЕТОМ, СЕРЦЕВО-СУДИННИМИ ЗАХВОРЮВАННЯМИ ТА COVID-19

Підвищений рівень холестерину ліпопротеїнів низької щільності (ЛПНЩ-Х), аполіпопротеїну В (АроВ), який в них міститься, та, особливо, окиснених ЛПНЩ у плазмі крові асоціюється із підвищеним ризиком розвитку серцево-судинних захворювань (СС3). Метою роботи було визначення рівня АроВ та окиснених ЛПНЩ у крові хворих на цукровий діабет (ЦД), CC3 та COVID-19. АроВ та окиснені ЛПНЩ визначали за допомогою наборів для імуноферментного аналізу (Elabscience, США). Вимірювання проводили при оптичній довжині хвилі 450 нм. Встановлено, що рівень АроВ та окиснених ЛПНЩ у крові хворих на ЦД i, особливо, з COVID-19 значно вищий, ніж у крові здорових людей. Рівень АроВ та окиснених ЛПНЩ у крові вище у пацієнтів і з COVID-19 і з діабетом або СC3 порівняно з пацієнтами з COVID-19 без супутніх захворювань. Таким чином, рівень АроВ та окиснених ЛПНЩ може бути перспективним маркером тяжкого COVID-19.

Ключові слова: COVID-19, діабет 2-го типу, сериево-судинні захворювання, аполіпопротеїн В, окиснені ЛПНЩ. 